\title{
The impact of chemotherapy-associated neutrophil/ lymphocyte counts on prognosis of adjuvant chemotherapy in colorectal cancer
}

Hong Chu-Yuan ${ }^{1}$, Peng Jing ${ }^{2}$, Wei Yi-Sheng ${ }^{1 *}$, Peng He-Ping ${ }^{2}$, Yang Hui ${ }^{3}$, Zhao Chu-Xiong ${ }^{1}$, Liang Guo-Jian ${ }^{1}$ and Wang Guo-Qiang ${ }^{1}$

\begin{abstract}
Background: Leukocytes play an important role in cancer development. However, the impact of chemotherapyassociated neutropenia/lymphopenia on the prognosis of adjuvant chemotherapy is unknown. Here, we aimed to explore the impact of chemotherapy-associated neutrophi//lymphocyte counts on prognosis of adjuvant chemotherapy in colorectal cancer (CRC) and the risk factors for developing neutropenia/lymphopenia which showed impact on the prognosis of CRC receiving adjuvant chemotherapy.
\end{abstract}

Methods: From February 2003 to January 2011, 243 stage II and III CRC patients receiving adjuvant chemotherapy were enrolled in this retrospective study. The associations between neutrophil/ lymphocyte counts and disease free survival (DFS)/overall survival (OS) of CRC, and the risk factors for neutropenia/lymphopenia were investigated.

Results: No association of chemotherapy-associated neutrophil counts and $C R C$ recurrence ( $A U C=0.474, P=0.534$ ), death ( $A \cup C=0.449, P=0.249$ ) was found by ROC analysis. However, the chemotherapy-associated lymphocyte counts could significantly affect $C R C$ recurrence $(A \cup C=0.634, P=0.001$ ), or death $(A \cup C=0.607, P=0.015$ ), with a optimized cut-off of $0.66 \times 10^{9} / \mathrm{L}$ for recurrence, and $0.91 \times 10^{9} / \mathrm{L}$ for death, respectively. Kaplan-Meier method showed chemotherapy-associated lymphopenia $<0.66 \times 10^{9} / \mathrm{L}$ was associated with shorter DFS $(P<0.0001)$, and chemotherapy-associated lymphopenia $<0.91 \times 10^{9} / \mathrm{L}$ was associated with shorter OS ( $\left.P=0.003\right)$. Cox regression model showed chemotherapy-associated lymphopenia $<0.66 \times 10^{9} / \mathrm{L}$ was the independent prognostic factor for DFS ( $\mathrm{HR}, 3.521 ; 95 \% \mathrm{Cl}=1.703-7.282)$, and chemotherapy-associated lymphopenia $<0.91 \times 10^{9} / \mathrm{L}$ was the independent prognostic factor for OS $(\mathrm{HR}, 2.083 ; 95 \% \mathrm{Cl}=1.103-3.936)$. Multivariate logistic regression showed the risk of developing chemotherapy-associated lymphopenia $<0.66 \times 10^{9} / \mathrm{L}$ was found in those with pretreatment $\mathrm{CEA} \geq 10 \mathrm{ng} \mathrm{ml}^{-1}(\mathrm{OR}, 3.338 ; 95 \% \mathrm{Cl}=1.523-7.315)$, and the risk of developing chemotherapy-associated lymphopenia $<0.91 \times 10^{9} / \mathrm{L}$ was found in those with age $>60$ years $(\mathrm{OR}, 2.872 ; 95 \% \mathrm{Cl}=1.344-6.136)$.

Conclusions: Chemotherapy-associated lymphopenia $<0.66 \times 10^{9} / \mathrm{L} / 0.91 \times 10^{9} / \mathrm{L}$ has a significant impact on the prognosis of CRC receiving adjuvant chemotherapy. Pretreatment CEA $\geq 10 \mathrm{ng} \mathrm{m}^{-1}$ is the independent risk factor for developing lymphopenia $<0.66 \times 10^{9} / \mathrm{L}$, and age $>60$ years is the independent risk factor for developing lymphopenia $<0.91 \times 10^{9} / \mathrm{L}$ during adjuvant chemotherapy of CRC.

Keywords: Colorectal cancer, Chemotherapy, Lymphopenia, Neutropenia, Prognosis

\footnotetext{
*Correspondence: yswei2004@126.com

'Department of Gastrointestinal Surgery, Lab of Surgery, the Second

Affiliated Hospital of Guangzhou Medical University, 250 Chang-gang-dong

Road, Guangzhou 510260Guangdong Province, China

Full list of author information is available at the end of the article
} 


\section{Background}

Colorectal cancer (CRC) is increasing in the world and China in recent years [1-3]. 5-Fu-based chemotherapy has been used to reduce the risk of relapse after surgery. 5 -Fu plus leucovorin with the addition of oxaliplatin chemotherapy(FOLFOX), which improved survival significantly compared with 5-FU alone [4], has been widely accepted as the standard adjuvant chemotherapy for stage III and stage II colorectal cancer. However, stage III patients have a $50-60 \%$ likelihood of tumor recurrence, and $20-30 \%$ of stage II patients will show recurrent disease [5]. Therefore, it is very important to select subgroups of patients who are most likely to be resistant to a given chemotherapy regimen.

In the past decades, several biomarkers such as microsatellite instability [6], Chromosome 18q allelic loss [7], TP53 mutation/overexpression [8,9], thymidylate synthase overexpression [9], Ki-67 overexpression [9], have been found to be associated with prognosis of colorectal cancer. However, some other reports failed to demonstrate the prognostic/predictive effect of the biomarkers mentioned above [10-12]. Thereby it is critical to identify the reliable biomarkers for prognosis of CRC patients receiving adjuvant chemotherapy. On the other hand, leukocytes play an important role in cancer development $[13,14]$. Thus, it seems that leukocytes variation may have some impact on the survival of colorectal cancer. However, whether neutropenia and lymphopenia, which are the common chemotherapy-induced toxicities, may influence the prognosis of adjuvant chemotherapy in CRC is unknown. Herein we explored the impact of chemotherapy-associated neutrophil/ lymphocyte counts on the prognosis of CRC patients receiving adjuvant chemotherapy. We also examined the risk factors affecting neutrophil or lymphocyte variation which showed impact on the prognosis of CRC patients receiving adjuvant chemotherapy to guide the individualized medicine for patients with CRC requiring chemotherapy.

\section{Methods}

\section{Patient selection}

From February 2003 to January 2011, stage II and III pathology-proven CRC patients who received FOLFOX regimen as adjuvant chemotherapy in the Second Affiliated Hospital of Guangzhou Medical University were enrolled in our retrospective study. Other eligibility criteria were as follows: At least 3 cycles of adjuvant chemotherapy, no tumor recurrence during chemotherapy, WHO performance status (PS) $0-1$, adequate pretreatment renal (pretreatment creatinine clearance $\geq 60 \mathrm{~mL} / \mathrm{min}$ ), and hepatic functions (pretreatment bilirubin $\leq 1.5$ upper limit of normal, pretreatment alanine aminotransferase and/or aspartate aminotransferase $\leq 2.5$ upper limit of normal), adequate baseline bone marrow (absolute baseline neutrophil counts $\geq 2.0 \times 10^{9}$ cells/L, absolute baseline lymphocyte counts $\geq 1.0 \times 10^{9}$ cells/L, baseline platelet counts $\geq 100 \times$ $10^{9}$ cells/L). The exclusion criteria included the following: biologic or immunotherapy, concomitant or neoadjuvant radiotherapy, previous systemic chemotherapy or neoadjuvant chemotherapy, primary prophylactic administration of granulocyte colony-stimulating factor (G-CSF) following chemotherapy, previous malignancies other than colorectal cancer, documented human immunosuppression. The evaluation of WHO PS and blood cell counts were performed before each next chemotherapy cycle and the lowest blood cell count was recorded in our study. The study was approved by the institutional review boards of Guangzhou Medical University.

\section{FOLFOX Treatment}

The FOLFOX regimen consisted of a 2-h intravenous infusion of oxaliplatin $\left(85 \mathrm{mg} / \mathrm{m}^{2}\right)$ and folinic acid $(400 \mathrm{mg} /$ $\mathrm{m}^{2}$ ), followed by an intravenous bolus injection of 5-FU $\left(400 \mathrm{mg} / \mathrm{m}^{2}\right)$ plus a $46-\mathrm{h}$ intravenous infusion of 5 -FU $\left(2400 \mathrm{mg} / \mathrm{m}^{2}\right)$, repeated every 2 weeks. Chemotherapy was delayed due to severe toxicity and the doses of oxaliplatin and 5-FU were reduced by $15 \%$ in subsequent cycles. Chemotherapy was discontinued due to unacceptable toxicity.

\section{Data collection and assessment of adjuvant chemotherapy prognosis}

From the medical records we collected the data of pretreatment albumin, pretreatment carcinoembryonic antigen (CEA), differentiation, sex, age, location, stage, blood cell counts. Albumin was divided into the following two groups: $\geq$ or $<35 \mathrm{~g} / \mathrm{L}$. CEA was divided into the following two groups: $\geq$ or $<10 \mathrm{ng} \mathrm{ml}^{-1}$. Duration of neutropenia $<1.5 \times 10^{9} / \mathrm{L} /$ lymphopenia $<1.0 \times 10^{9} \mathrm{~L}$ was divided into the following two groups: $>28$ days or $\leq 28$ days, respectively. Staging was performed according to the American Joint Committee on Cancer (AJCC, seventh edition).

\section{Statistical analysis}

The prognostic value of chemotherapy-associated neutrophil/lymphocyte counts on tumor recurrence, death was analyzed by Receiver Operating Characteristic (ROC) analysis to select the best cut-off of neutrophil/lymphocyte counts. Kaplan-Meier method was used to estimate disease free survival (DFS) / overall survival (OS). Multivariate analysis and Cox proportional hazard models were used to determine the independent impact of chemotherapyassociated neutrophil/lymphocyte counts on DFS/OS. The risk factors for neutrophil or lymphocyte counts abnormality which showed impact on DFS/OS of stage II-III CRC receiving adjuvant chemotherapy were analyzed by the unconditional logistic regression model. All statistical analyses 
were performed by Statistical Package of Social Sciences 17.0 software and 2 -sided. $\mathrm{P}$ value $<0.05$ was considered to be statistically significant.

\section{Results}

\section{Characteristics of the study population}

There were 243 CRC patients who fulfilled the eligibility and exclusion criteria in the present study. The characteristics of the studied population were shown in Table 1. Of the 243 cases, 21 cases had to stop adjuvant chemotherapy for severe toxicity. The median age of 243 cases was 59 years with a range of $22-82$ years. The median follow-up time was 31 months (range 7-103 months). Of the 243 cases, $109(44.9 \%)$ were female and 134 (55.1\%) were male. $111(45.7 \%)$ cases were rectal cancer, 77(31.7\%) cases were left colon cancer, and 55 (22.6\%) were right colon cancer. According to the American Joint Committee on Cancer (AJCC, seventh edition), there were $140(57.6 \%)$ stage II cases and 103(42.4\%) stage III cases. The population in our study had a mean baseline neutrophil counts of $4.27 \pm 1.49 \times 10^{9} / \mathrm{L}$, a mean baseline lymphocyte counts of $1.88 \pm 0.59 \times 10^{9} / \mathrm{L} .90$ (37.0\%) cases experienced neutropenia $<1.5 \times 10^{9} / \mathrm{L}$ and 104(42.8\%) cases experienced lymphopenia $<1.0 \times 10^{9} / \mathrm{L}$ during chemotherapy. According to National Cancer Institute Common Terminology Criteria for Adverse Events version 3.0 (NCI-CTC), grade $3 / 4$ neutropenia was observed in $49(20.2 \%)$ cases and grade $3 / 4$ lymphopenia was observed in $15(6.2 \%)$ cases. $4(1.6 \%)$ cases suffered from neutropenic infection requiring hospitalization and treatment with intravenous antibiotics at 5 cycles of chemotherapy.

\section{The prognostic value of chemotherapy-associated} neutrophil/ lymphocyte counts on CRC recurrence/death The cut-offs according to NCI-CTC may not be reliable to evaluate the impact of chemotherapy-associated neutrophil/lymphocyte counts on the prognosis of CRC receiving adjuvant chemotherapy. We investigated the prognostic value of chemotherapy-associated neutrophil/ lymphocyte counts on CRC recurrence, death by ROC analysis to select the best cut-off. No association of chemotherapy-associated neutrophil counts and tumor recurrence, death was found. The area under curve (AUC) of chemotherapy-associated neutrophil counts for CRC recurrence, death was $0.474(\mathrm{P}=0.534), 0.449(\mathrm{P}=$ 0.249 ), respectively (Figure 1 ). However, the significance was found between chemotherapy-associated lymphocyte counts and CRC recurrence, death. The AUC of chemotherapy-associated lymphocyte counts, was 0.634 for $\mathrm{CRC}$ recurrence $(\mathrm{P}=0.001), 0.607$ for death $(\mathrm{P}=0.015)$, respectively (Figure 2 ). We then evaluated the best cut-off of chemotherapy-associated lymphocyte level affecting $\mathrm{CRC}$ recurrence, death with the highest value of sensitivity
Table 1 Patient characteristics

\begin{tabular}{|c|c|c|}
\hline Variables & Number of cases & Percentage(\%) \\
\hline \multicolumn{3}{|l|}{ Follow-up(months) } \\
\hline Median(range) & $31(7-103)$ & \\
\hline \multicolumn{3}{|l|}{ Age(years) } \\
\hline Median(range) & $59(22-82)$ & \\
\hline \multicolumn{3}{|l|}{ Pretreatment albumin } \\
\hline$\geq 35 \mathrm{~g} / \mathrm{L}$ & 173 & 71.2 \\
\hline$<35 \mathrm{~g} / \mathrm{L}$ & 70 & 28.8 \\
\hline \multicolumn{3}{|l|}{ Pretreatment $C E A^{a}$} \\
\hline$\leq 10 \mathrm{ng} / \mathrm{ml}$ & 186 & 76.5 \\
\hline$>10 \mathrm{ng} / \mathrm{ml}$ & 57 & 23.5 \\
\hline \multicolumn{3}{|l|}{ Differentiation } \\
\hline High & 24 & 9.9 \\
\hline Middle & 198 & 81.5 \\
\hline Low & 21 & 8.6 \\
\hline \multicolumn{3}{|l|}{ Sex } \\
\hline Male & 134 & 55.1 \\
\hline Female & 109 & 44.9 \\
\hline \multicolumn{3}{|l|}{ Age } \\
\hline$\leq 49$ years & 56 & 23.0 \\
\hline $50-60$ yeas & 72 & 29.6 \\
\hline$>60$ years & 115 & 47.3 \\
\hline \multicolumn{3}{|l|}{ am } \\
\hline Rectum & 111 & 45.7 \\
\hline Left colon cancer & 77 & 31.7 \\
\hline Right colon cancer & 55 & 22.6 \\
\hline \multicolumn{3}{|l|}{ Stage } \\
\hline$\|$ & 140 & 57.6 \\
\hline III & 103 & 42.4 \\
\hline \multicolumn{3}{|c|}{ Baseline neutrophil counts $\left(\times 10^{9} / \mathrm{L}\right)$} \\
\hline Mean $( \pm S D)$ & $4.27 \pm 1.49$ & \\
\hline \multicolumn{3}{|c|}{ Baseline lymphocyte counts $\left(\times 10^{9} / L\right)$} \\
\hline Mean $( \pm$ SD) & $1.88 \pm 0.59$ & \\
\hline \multicolumn{3}{|c|}{ Chemotherapy-associated neutrophil counts } \\
\hline Neutrophil counts $\geq 1.5 \times 10^{9} / \mathrm{L}$ & 153 & 63.0 \\
\hline Neutropenia $<1.5 \times 10^{9} / \mathrm{L}$ & 90 & 37.0 \\
\hline \multicolumn{3}{|c|}{ Chemotherapy-associated lymphocyte counts } \\
\hline Lymphocyte counts $\geq 1.0 \times 10^{9} / \mathrm{L}$ & 139 & 57.2 \\
\hline Lymphopenia $<1.0 \times 10^{9} / \mathrm{L}$ & 104 & 42.8 \\
\hline
\end{tabular}

${ }^{\mathrm{a}}$ Carcinoembryonic antigen.

plus specificity by ROC analysis. The best prognostic cutoff was $0.66 \times 10^{9} / \mathrm{L}$ for CRC recurrence, $0.91 \times 10^{9} / \mathrm{L}$ for death, respectively. $42(17.3 \%)$ cases had chemotherapyassociated lymphopenia $<0.66 \times 10^{9} / \mathrm{L}$ and $90(37.0 \%)$ cases had chemotherapy-associated lymphopenia $<0.91 \times 10^{9} / \mathrm{L}$ in this study. 

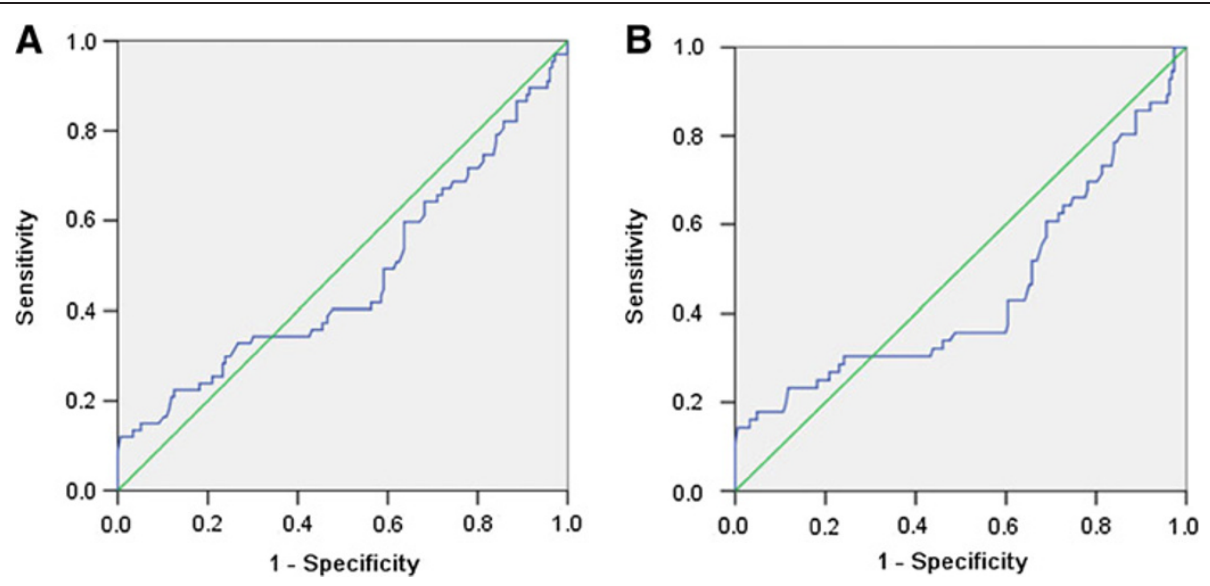

Figure 1 ROC curve of chemotherapy-associated neutrophil counts affecting CRC recurrence, death. (A) The area under curve (AUC) of chemotherapy-associated neutrophil counts for CRC recurrence was 0.474 and P value was 0.534 . (B) The AUC of chemotherapy-associated neutrophil counts for CRC death was was 0.449 and $P$ value was 0.249 .

The prognostic value of chemotherapy-associated lymphopenia $<0.66 \times 10^{9} / \mathrm{L}, 0.91 \times 10^{9} / \mathrm{L}$ for colorectal cancer

Therefore, we selected $0.66 \times 10^{9} / \mathrm{L}, 0.91 \times 10^{9} / \mathrm{L}$ which were found by ROC analysis as the cut-offs to investigate the impact of chemotherapy-associated lymphopenia on DFS, OS of CRC receiving adjuvant chemotherapy. Kaplan-Meier method showed chemotherapy-associated lymphopenia $<0.66 \times 10^{9} / \mathrm{L}$ was associated with shorter DFS $(\mathrm{P}<0.0001)$, whereas chemotherapy-associated lymphopenia $<0.91 \times 10^{9} / \mathrm{L}$ was associated with shorter OS $(\mathrm{P}=0.003)$ (Figure 3$)$. To control the possible confounding of the main effects of chemotherapyassociated lymphopenia $<0.66 \times 10^{9} / \mathrm{L} / 0.91 \times 10^{9} / \mathrm{L}$ on DFS/OS, respectively, the clinicopathological factors (pretreatment albumin, pretreatment CEA, differentiation, sex, age, location and stage) and duration of lymphopenia $<1.0 \times 10^{9} \mathrm{~L}$ were further adjusted for in the multivariate cox regression model. As shown in Table 2, cox regression model showed chemotherapyassociated lymphopenia $<0.66 \times 10^{9} / \mathrm{L}(\mathrm{HR}, 3.521 ; 95 \%$ $\mathrm{CI}=1.703-7.282)$, pretreatment $\mathrm{CEA} \geq 10 \mathrm{ng} \mathrm{ml}^{-1}(\mathrm{HR}$, 1.827; $95 \% \mathrm{CI}=1.040-3.211$ ), stage III (HR, 2.723; $95 \%$ $\mathrm{CI}=1.549-4.786)$ were independent prognostic factors for DFS, and 99 (40.7\%) cases had all of those negative prognostic factors. Moreover, as shown in Table 3, cox regression model showed chemotherapy-associated lymphopenia $<0.91 \times 10^{9} / \mathrm{L}(\mathrm{HR}, 2.083 ; 95 \% \mathrm{CI}=1.103-3.936)$, pretreatment $\mathrm{CEA} \geq 10 \mathrm{ng} \mathrm{ml}^{-1}$ (HR, 1.900; 95\% CI = 1.056-3.416), stage III (HR, 3.641; 95\% CI $=1.980-6.697)$
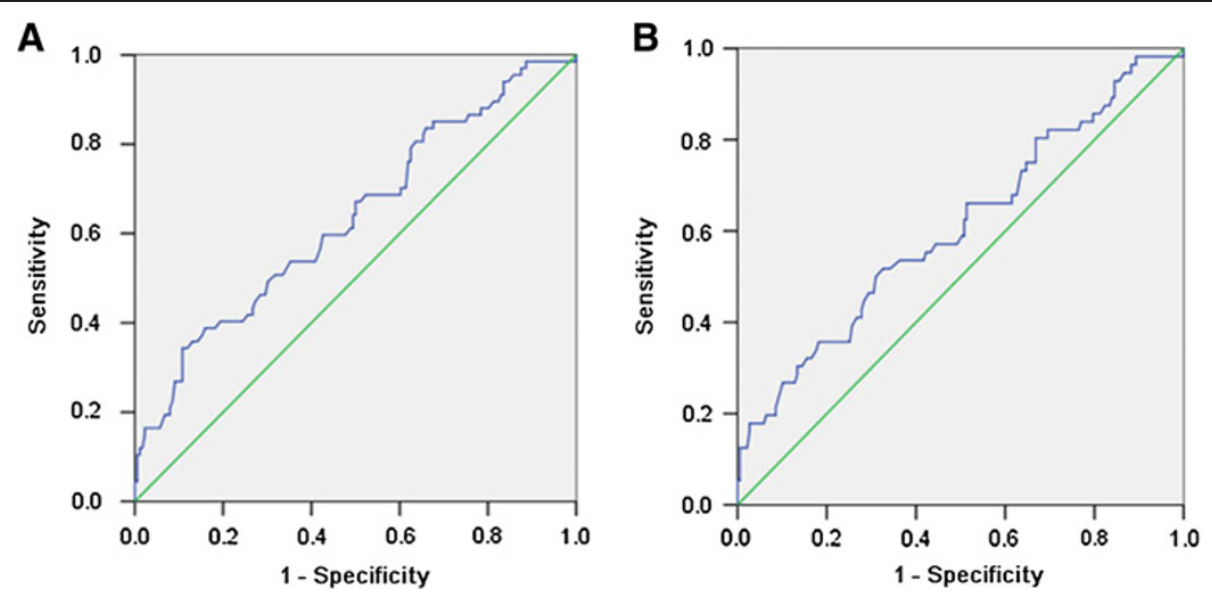

Figure 2 ROC curve of chemotherapy-associated lymphocyte counts affecting CRC recurrence, death. (A) The area under curve (AUC) of chemotherapy-associated neutrophil counts for CRC recurrence was 0.634 and P value was 0.001 . (B) The AUC of chemotherapy-associated neutrophil counts for CRC death was was 0.607 and P value was 0.015 . 

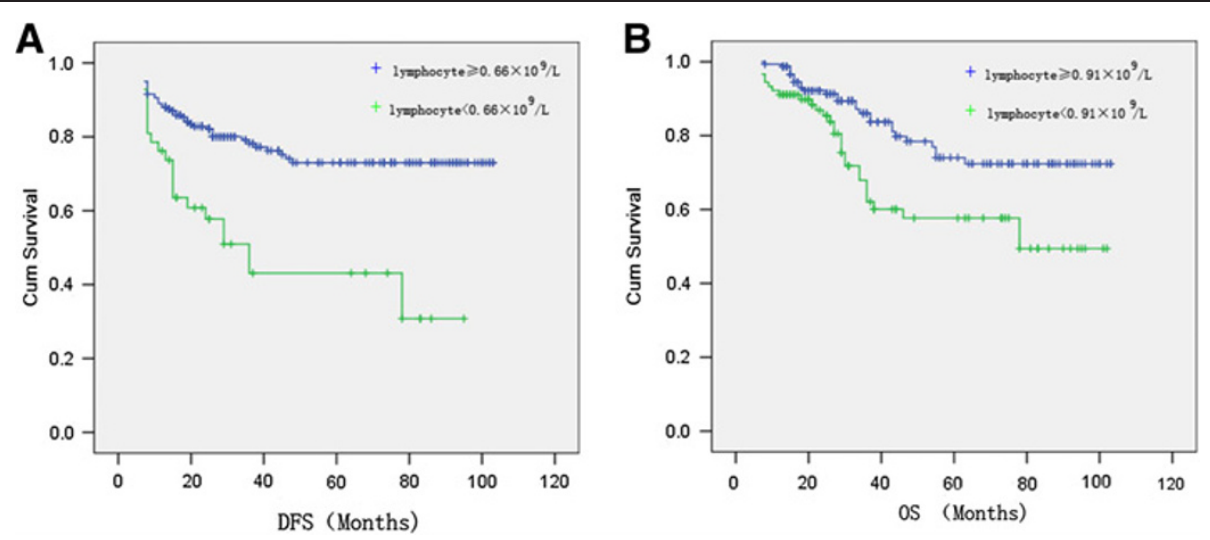

Figure 3 DFS, OS curve by Kaplan-Meier method. (A) Chemotherapy-associated lymphopenia $<0.66 \times 10^{9} / L$ was associated with shorter DFS and $P$ value was $<0.0001$. (B) Chemotherapy-associated lymphopenia $<0.91 \times 10^{9} / \mathrm{L}$ was associated with shorter OS and $P$ value was 0.003 .

were independent prognostic factors for OS, and 77 (31.7\%) cases had all of those negative prognostic factors.

\section{The risk factors for chemotherapy-associated lymphopenia $<0.66 \times 10^{9} / \mathrm{L} / 0.91 \times 10^{9} / \mathrm{L}$ in colorectal cancer}

Then the clinicopathological factors (pretreatment albumin, pretreatment CEA, differentiation, sex, age, location, stage) were included in the multivariate logistic regression model to explore the independent risk factors for chemotherapy-associated lymphopenia $<0.66 \times 10^{9} / \mathrm{L} /$ $0.91 \times 10^{9} / \mathrm{L}$ in colorectal cancer. As shown in Table 4 and Table 5, pretreatment CEA $\geq 10 \mathrm{ng} \mathrm{ml}^{-1}$ was the independent risk factor for chemotherapy-associated lymphopenia $<0.66 \times 10^{9} / \mathrm{L}(\mathrm{OR}, 3.338 ; 95 \% \mathrm{CI}=1.523$ 7.315 ), and age $>60$ years was the independent risk factor for chemotherapy-associated lymphopenia $<0.91 \times$ $10^{9} / \mathrm{L}(\mathrm{OR}, 2.872$; $95 \% \mathrm{CI}=1.344-6.136)$.

\section{Discussion}

In the present study, we investigated the impact of chemotherapy-associated neutrophil/lymphocyte counts on prognosis of CRC receiving adjuvant chemotherapy. We found chemotherapy-associated lymphopenia, but not neutropenia to be associated with CRC recurrence, death after adjuvant chemotherapy. The best lymphopenic cut-off affecting CRC recurrence was $0.66 \times 10^{9} / \mathrm{L}$, and that affecting CRC death was $0.91 \times 10^{9} / \mathrm{L}$. Chemotherapyassociated lymphopenia $<0.66 \times 10^{9} / \mathrm{L} / 0.91 \times 10^{9} / \mathrm{L}$ was the independent prognostic factor for worse DFS/OS, respectively, in stage II and III CRC receiving adjuvant chemotherapy. Pretreatment CEA $\geq 10 \mathrm{ng} \mathrm{ml}^{-1}$ was the independent risk factor for chemotherapy-associated lymphopenia $<0.66 \times 10^{9} / \mathrm{L}$, and age $>60$ years was the independent risk factor for chemotherapy-associated lymphopenia $<0.91 \times$ $10^{9} / \mathrm{L}$ in CRC receiving adjuvant chemotherapy.
It is reported that circulating lymphocytes play a central role in anti-tumor effect. Lymphodepletion due to the altered bone marrow microenvironment was observed in the ApcMin/+ mouse model of intestinal tumorigenesis [15], which indicates the lymphodepletion may contribute to the drop of anti-tumor immune and tumorigenesis. Due to interplay between soluble factors such as cytokines, chemokines, surface receptors and adhesion molecules, progression and invasion occur in a dynamic microenvironment involving the complex communications between tumor cells and many types of immune cells including the various types of lymphocytes [16]. Thus,lymphopenia is supposed to account for the adverse anti-tumor microenvironment. Moreover, lymphopenia is associated with increased circulating levels of IL-7 [17,18]. IL-7 plays an oncogenic role promoting proliferation, lymphangiogenesis and metastasis in neoplasm [19-23]. That may partly explain the clinical outcome of chemotherapy-associated lymphopenia in colorectal cancer in our study. Recently, pretreatment peripheral blood lymphocytes have been found to show a significant impact on the complete response rate in response to preoperative radiotherapy in locally advanced rectal cancer (RC) patients and lymphocytemediated immune reactions are supposed to have positive roles in radiosensitivity for RC [24]. Likewise, pretreatment lymphopenia is an independent risk factor for shorter survival of palliative chemotherapy in colorectal cancer [25]. Moreover, pretreatment lymphopenia has been found to be the independent risk factor for Peripheral T-cell lymphoma, not otherwise specified (PTCL-NOS) [26], metastatic breast carcinoma [27], advanced soft tissue sarcoma [27] and nonHodgkin's lymphoma [27]. Lymphopenia is a common adverse event during chemotherapy with the incidence $>25 \%$ $[28,29]$. However, the clinical significance of chemotherapyassociated lymphocyte drop in the adjuvant chemotherapy of CRC is unclear. That indicated lymphopenia, which is 
Table 2 Prognostic value of chemotherapy-associated lymphopenia $<0.66 \times 10^{9} / \mathrm{L}$ for DFS of colorectal cancer

\begin{tabular}{|c|c|c|c|}
\hline Variables & Hazard ratio & $\mathbf{9 5} \%$ confidence intervals & P-value \\
\hline \multicolumn{4}{|l|}{ Pretreatment albumin } \\
\hline$\geq 35 \mathrm{~g} / \mathrm{L}$ & 1.00 (ref.) & & \\
\hline$<35 \mathrm{~g} / \mathrm{L}$ & 1.000 & $0.592-1.692$ & 0.999 \\
\hline \multicolumn{4}{|l|}{ Pretreatment CEA ${ }^{a}$} \\
\hline$<10 \mathrm{ng} \mathrm{ml}^{-1}$ & 1.00 (ref.) & & \\
\hline$\geq 10 \mathrm{ng} \mathrm{ml}^{-1}$ & 1. 827 & $1.040-3.211$ & 0.036 \\
\hline \multicolumn{4}{|l|}{ Differentiation } \\
\hline Well & 1.00 (ref.) & & \\
\hline Moderately & 0.676 & $0.292-1.567$ & 0.361 \\
\hline Low & 0.882 & $0.294-2.644$ & 0.823 \\
\hline \multicolumn{4}{|l|}{ Sex } \\
\hline Male & 1.00 (ref.) & & \\
\hline Female & 1.018 & $0.616-1.682$ & 0.946 \\
\hline \multicolumn{4}{|l|}{ Age } \\
\hline$\leq 49$ years & 1.00 (ref.) & & \\
\hline $50-60$ yeas & 1.612 & $0.750-3.465$ & 0.222 \\
\hline$>60$ years & 1.386 & $0.673-2.854$ & 0.376 \\
\hline \multicolumn{4}{|l|}{ Location } \\
\hline Rectum & 1.00(ref.) & & \\
\hline Left colon cancer & 0.873 & $0.483-1.576$ & 0.651 \\
\hline Right colon cancer & 0.850 & $0.438-1.649$ & 0.630 \\
\hline \multicolumn{4}{|l|}{ Stage } \\
\hline$\|$ & 1.00 (ref.) & & \\
\hline III & 2.723 & $1.549-4.786$ & 0.001 \\
\hline \multicolumn{4}{|c|}{ Duration of lymphopenia $<1.0 \times 10^{9} \mathrm{~L}$} \\
\hline$\leq 28$ days & 1.00 (ref.) & & \\
\hline$>28$ days & 0.556 & $0.243-1.273$ & 0.165 \\
\hline \multicolumn{4}{|c|}{ Chemotherapy-associated lymphocyte counts } \\
\hline Lymphocyte counts $\geq 0.66 \times 10^{9} / \mathrm{L}$ & 1.00 (ref.) & & \\
\hline Lymphopenia $<0.66 \times 10^{9} / \mathrm{L}$ & 3.521 & $1.703-7.282$ & 0.001 \\
\hline
\end{tabular}

${ }^{a}$ Carcinoembryonic antigen.

the common chemotherapy-induced toxity, may be the possible mechanism for the failure of adjuvant chemotherapy in CRC. Our study also showed chemotherapyassociated neutropenia had no impact on DFS, OS of $\mathrm{CRC}$, suggesting lymphopenia rather than neutropenia may play an important role in the variation of antitumor immune reaction during adjuvant chemotherapy in CRC. Chemotherapy-associated lymphopenia is reported rarely in clinical trials. To the best of our knowledge, our study demonstrated the impact of chemotherapy-associated lymphopenia on the clinical outcome of adjuvant chemotherapy in CRC for the first time.

The cut-off of lymphopenia is different in previous studies. Some reports defined lymphopenia as a lymphocyte count of less than $1.5 \times 10^{9} / \mathrm{L}$ [30-32], while some other reports chose the threshold level of $1.0 \times 10^{9} / \mathrm{L}[25,27]$. However, when we chose the threshold level of $1.0 \times 10^{9} / \mathrm{L}$ in the present study, lymphopenia $<1.0 \times 10^{9} / \mathrm{L}$ was not the independent risk factor for worse DFS,OS in stage II and III CRC receiving adjuvant chemotherapy(data not shown). Therefore, the cut-offs mentioned above may not be suitable for the evaluation of lymphocyte counts on prognosis of CRC receiving adjuvant chemotherapy. ROC analysis showed the best cut-off of lymphopenia was $0.66 \times$ $10^{9} / \mathrm{L}$ for CRC recurrence, $<0.91 \times 10^{9} / \mathrm{L}$ for CRC death in this study and Cox regression model as well as KaplanMeier method confirmed the prognostic value of lymphopenia $<0.66 \times 10^{9} / \mathrm{L}$ for DFS,lymphopenia $<0.91 \times$ 
Table 3 Prognostic value of chemotherapy-associated lymphopenia $<0.91 \times 10^{9} / \mathrm{L}$ for OS of colorectal cancer

\begin{tabular}{|c|c|c|c|}
\hline Variables & Hazard ratio & $\mathbf{9 5} \%$ confidence intervals & P-value \\
\hline \multicolumn{4}{|l|}{ Pretreatment albumin } \\
\hline$\geq 35 \mathrm{~g} / \mathrm{L}$ & 1.00 (ref.) & & \\
\hline$<35 \mathrm{~g} / \mathrm{L}$ & 1.140 & $0.648-2.007$ & 0.649 \\
\hline \multicolumn{4}{|l|}{ Pretreatment CEA ${ }^{a}$} \\
\hline$<10 \mathrm{ng} \mathrm{ml}^{-1}$ & 1.00 (ref.) & & \\
\hline$\geq 10 \mathrm{ng} \mathrm{ml}^{-1}$ & 1. 900 & $1.056-3.416$ & 0.032 \\
\hline \multicolumn{4}{|l|}{ Differentiation } \\
\hline Well & 1.00 (ref.) & & \\
\hline Moderately & 0.865 & $0.323-2.314$ & 0.772 \\
\hline Low & 1.097 & $0.311-3.871$ & 0.885 \\
\hline \multicolumn{4}{|l|}{ Sex } \\
\hline Male & 1.00 (ref.) & & \\
\hline Female & 0.856 & $0.493-1.489$ & 0.583 \\
\hline \multicolumn{4}{|l|}{ Age } \\
\hline$\leq 49$ years & 1.00 (ref.) & & \\
\hline $50-60$ yeas & 1.514 & $0.625-3.666$ & 0.359 \\
\hline$>60$ years & 1.587 & $0.698-3.607$ & 0.271 \\
\hline \multicolumn{4}{|l|}{ Location } \\
\hline Rectum & 1.00(ref.) & & \\
\hline Left colon cancer & 1.067 & $0.564-2.019$ & 0.843 \\
\hline Right colon cancer & 0.647 & $0.296-1.414$ & 0.275 \\
\hline \multicolumn{4}{|l|}{ Stage } \\
\hline$\|$ & 1.00 (ref.) & & \\
\hline III & 3.641 & $1.980-6.697$ & $<0.0001$ \\
\hline \multicolumn{4}{|c|}{ Duration of lymphopenia $<1.0 \times 10^{9} \mathrm{~L}$} \\
\hline$\leq 28$ days & 1.00 (ref.) & & \\
\hline$>28$ days & 0.770 & $0.341-1.740$ & 0.530 \\
\hline \multicolumn{4}{|c|}{ Chemotherapy-associated lymphocyte counts } \\
\hline Lymphocyte counts $\geq 0.66 \times 10^{9} / \mathrm{L}$ & 1.00 (ref.) & & \\
\hline Lymphopenia $<0.66 \times 10^{9} / \mathrm{L}$ & 2.083 & $1.103-3.936$ & 0.024 \\
\hline
\end{tabular}

${ }^{a}$ Carcinoembryonic antigen.

$10^{9} / \mathrm{L}$ for OS. Thus, it is reasonable that chemotherapyassociated lymphopenia $<0.66 \times 10^{9} / \mathrm{L} / 0.91 \times 10^{9} / \mathrm{L}$ is a simple biomarker affecting worse DFS/OS,respectively, for stage II and III CRC receiving adjuvant chemotherapy. Lymphopenia $<0.66 \times 10^{9} / \mathrm{L} / 0.91 \times 10^{9} / \mathrm{L}$ can be the cutoffs to guide the individualized medicine in adjuvant chemotherapy of colorectal cancer.

Moreover, though chemotherapy associated lymphopenia $<0.66 \times 10^{9} / \mathrm{L} / 0.91 \times 10^{9} / \mathrm{L}$ showed a longer duration of duration of lymphopenia $<1.0 \times 10^{9} \mathrm{~L}$ compared with lymphopenia $\geq 0.66 \times 10^{9} / \mathrm{L} / 0.91 \times 10^{9} / \mathrm{L}(80.76 \pm 49.64$ days vs $7.43 \pm 12.38$ days, $51.84 \pm 43.79$ days vs $1.43 \pm 5.01$ days, respectively, data not shown), cox regression model showed lymphopenia $<0.66 \times 10^{9} / \mathrm{L} / 0.91 \times 10^{9} / \mathrm{L}$, but not duration of lymphopenia $<1.0 \times 10^{9} \mathrm{~L}$, was the independent prognostic factor. That suggest chemotherapy-associated lymphopenia level, rather than duration of lymphopenia $<1.0 \times 10^{9} / \mathrm{L}$, may play an important role in the prognosis of CRC receiving adjuvant chemotherapy.

The previous studies reported lymphopenia could be affected by various factors including vitamin D deficiency [32], weight loss [33], variation of circulating metal ions levels [34], malnutrition [35]. However, our study showed pretreatment CEA $\geq 10 \mathrm{ng} \mathrm{ml}^{-1}$ was the only independent risk factor for chemotherapy-associated lymphopenia $<0.66 \times 10^{9} / \mathrm{L}$, and age $>60$ years was the 
Table 4 The risk factors for chemotherapy-associated lymphopenia $<0.66 \times 10^{9} / \mathrm{L}$ in colorectal cancer by multivariate logistic regression model

\begin{tabular}{|c|c|c|c|}
\hline Variables & Odds ratio & 95\% confidence intervals & P-value \\
\hline \multicolumn{4}{|c|}{ Pretreatment albumin } \\
\hline$\geq 35 \mathrm{~g} / \mathrm{L}$ & 1.00 (ref.) & & \\
\hline$<35 \mathrm{~g} / \mathrm{L}$ & 0.685 & $0.302-1.550$ & 0.363 \\
\hline \multicolumn{4}{|l|}{ Pretreatment CEA ${ }^{a}$} \\
\hline$<10 \mathrm{ng} \mathrm{ml}^{-1}$ & 1.00 (ref.) & & \\
\hline$\geq 10 \mathrm{ng} \mathrm{ml}^{-1}$ & 3.338 & $1.523-7.315$ & 0.003 \\
\hline \multicolumn{4}{|l|}{ Differentiation } \\
\hline Well & 1.00(ref.) & & \\
\hline Moderately & 1.200 & $0.308-4.678$ & 0.793 \\
\hline Low & 3.049 & $0.553-16.828$ & 0.201 \\
\hline \multicolumn{4}{|l|}{ Sex } \\
\hline Male & 1.00 (ref.) & & \\
\hline Female & 1.219 & $0.600-2.474$ & 0.584 \\
\hline \multicolumn{4}{|l|}{ Age } \\
\hline$\leq 49$ years & 1.00 (ref.) & & \\
\hline $50-60$ yeas & 0.840 & $0.271-2.608$ & 0.763 \\
\hline$>60$ years & 2.358 & $0.904-6.154$ & 0.080 \\
\hline \multicolumn{4}{|l|}{ Location } \\
\hline Rectum & 1.00 (ref.) & & \\
\hline Left colon cancer & 1.056 & $0.484-2.300$ & 0.892 \\
\hline Right colon cancer & 0.532 & $0.192-1.475$ & 0.225 \\
\hline \multicolumn{4}{|l|}{ Stage } \\
\hline$\|$ & 1.00(ref.) & & \\
\hline III & 0.847 & $0.403-1.781$ & 0.661 \\
\hline
\end{tabular}

${ }^{\mathrm{a}}$ Carcinoembryonic antigen.

only independent risk factor for chemotherapy-associated lymphopenia $<0.91 \times 10^{9} / \mathrm{L}$ in colorectal cancer, suggesting those who have a pretreatment CEA $\geq 10 \mathrm{ng} \mathrm{ml}^{-1}$ are predispose to lymphopenia $<0.66 \times 10^{9} / \mathrm{L}$, meanwhile those $>60$ years old are predispose to lymphopenia $<0.91 \times 10^{9} /$ $\mathrm{L}$ during adjuvant chemotherapy. Thus, pretreatment CEA $\geq 10 \mathrm{ng} \mathrm{ml}^{-1}$ and age $>60$ years should be taken into account in the individualized medicine in adjuvant chemotherapy of CRC to reduce the risk of chemotherapyassociated lymphopenia and improve survival. The rate of grade 3/4 neutropenia in our study was lower than that in the MOSAIC study (41.1\%) [36]. In MOSAIC study, FOLFOX was administered to those who have neutrophil counts $>1.5 \times 109 / \mathrm{L}$, while those with baseline neutrophil counts $\geq 2.0 \times 10^{9}$ cells $/ \mathrm{L}$ were included in our study. That may contribute to the difference in the severity of neutropenia.

However, there are some limitations in the present study. The sample size was relatively small. Therefore
Table $\mathbf{5}$ The risk factors for chemotherapy-associated lymphopenia $<0.91 \times 10^{9} / \mathrm{L}$ in colorectal cancer by multivariate logistic regression model

\begin{tabular}{|c|c|c|c|}
\hline Variables & Odds ratio & $\mathbf{9 5 \%}$ confidence intervals & P-value \\
\hline \multicolumn{4}{|c|}{ Pretreatment albumin } \\
\hline$\geq 35 \mathrm{~g} / \mathrm{L}$ & 1.00(ref.) & & \\
\hline$<35 \mathrm{~g} / \mathrm{L}$ & 1.410 & $0.772-2.576$ & 0.263 \\
\hline \multicolumn{4}{|l|}{ Pretreatment CEA ${ }^{a}$} \\
\hline$<10 \mathrm{ng} \mathrm{m}^{-1}$ & 1.00 (ref.) & & \\
\hline$\geq 10 \mathrm{ng} \mathrm{ml}^{-1}$ & 1.885 & $0.984-3.610$ & 0.056 \\
\hline \multicolumn{4}{|l|}{ Differentiation } \\
\hline Well & 1.00 (ref.) & & \\
\hline Moderately & 1.590 & $0.564-4.483$ & 0.381 \\
\hline Low & 2.694 & $0.694-10.458$ & 0.152 \\
\hline \multicolumn{4}{|l|}{ Sex } \\
\hline Male & 1.00(ref.) & & \\
\hline Female & 1.725 & $0.987-3.016$ & 0.056 \\
\hline \multicolumn{4}{|l|}{ Age } \\
\hline$\leq 49$ years & 1.00(ref.) & & \\
\hline $50-60$ yeas & 1.617 & $0.705-3.709$ & 0.256 \\
\hline$>60$ years & 2.872 & $1.344-6.136$ & 0.006 \\
\hline \multicolumn{4}{|l|}{ Location } \\
\hline Rectum & 1.00(ref.) & & \\
\hline Left colon cancer & 0.948 & $0.502-1.789$ & 0.869 \\
\hline Right colon cancer & 0.780 & $0.381-1.596$ & 0.496 \\
\hline \multicolumn{4}{|l|}{ Stage } \\
\hline$\|$ & 1.00(ref.) & & \\
\hline III & 0.881 & $0.494-1.572$ & 0.668 \\
\hline
\end{tabular}

the conclusions, such as the cut-offs of lymphopenia, should be proven by the larger, multicenter study. We also await the further functional analyses of circulating lymphocyte subpopulations that contribute to prognosis of $\mathrm{CRC}$ receiving adjuvant chemotherapy.

\section{Conclusions}

In conclusion, our study indicated chemotherapy-associated lymphopenia $<0.66 \times 10^{9} / \mathrm{L} / 0.91 \times 10^{9} / \mathrm{L}$ was associated with worse prognosis in adjuvant chemotherapy of CRC. Chemotherapy-associated lymphopenia is supposed to reflect the immunosuppression state which has an adverse impact on the anti-tumor effect and may partly explain the failure of adjuvant chemotherapy in CRC. Circulating lymphocyte counts should be monitored during chemotherapy to guide individualized medicine in adjuvant chemotherapy of CRC, especially for those who have a pretreatment CEA $\geq 10 \mathrm{ng} \mathrm{ml}^{-1}$ or those $>60$ years old. 


\section{Abbreviations}

CRC: Colorectal cancer; FOLFOX: 5-Fu plus leucovorin with the addition of oxaliplatin chemotherapy; DFS: Disease free survival; PS: Performance status; G-CSF: Granulocyte colony-stimulating factor; CEA: Carcinoembryonic antigen; OS: Overall survival; ROC: Receiver Operating Characteristic; AJCC: The American Joint Committee on Cancer; AUC: Area under curve; $\mathrm{RC}$ : Rectal cancer.

\section{Competing interests}

The authors declare that they have no competing interests.

\section{Authors' contributions}

HCY and WYS designed the study, performed the statistical analysis and drafted the manuscript. PJ and WGQ collected the clinical data. PHP, YH, ZCX, LGJ participated in its design and coordination and helped to draft the manuscript. All authors read and approved the final manuscript.

\section{Acknowledgements}

This work was supported by the National Natural Scientific Foundation of China Grants [81001108 to Yisheng Wei, 81001109 to Hui Yang].

\section{Author details}

'Department of Gastrointestinal Surgery, Lab of Surgery, the Second Affiliated Hospital of Guangzhou Medical University, 250 Chang-gang-dong Road, Guangzhou 510260Guangdong Province, China. ${ }^{2}$ Department of General Surgery, Lab of Surgery, the Second Affiliated Hospital of Guangzhou Medical University, 250 Chang-gang-dong Road, Guangzhou $510260 G$ uangdong Province, China. ${ }^{3}$ Department of Gastroenterology, the Second Affiliated Hospital of Guangzhou Medical University, 250 Changgang-dong Road, Guangzhou 510260Guangdong Province, China.

Received: 29 March 2012 Accepted: 6 February 2013

Published: 3 April 2013

\section{References}

1. Xu AG, Jiang B, Yu ZJ, Zhong XH, Gan AH, Liu JH, Luo QY, Xiong LS: Epidemiology investigation of colorectal cancer on community group in Guangdong province. Zhonghua Yi Xue Za Zhi 2007, 87(28):1950-1953.

2. Coleman MP, Quaresma M, Berrino F, Lutz JM, De Angelis R, Capocaccia R, Baili P, Rachet B, Gatta G, Hakulinen T, et al: Cancer survival in five continents: a worldwide population-based study (CONCORD). Lancet Oncol 2008, 9(8):730-756.

3. Cao KJ, Fan QY, Liu YL, Huang R, Yin CZ, Ma GS, Liu ZQ, Wan DS, Zeng YX: Cancer incidence and mortality in Guangzhou City from 2000 to 2002. Ai Zheng 2008, 27(3):225-230.

4. Andre T, Boni C, Navarro M, Tabernero J, Hickish T, Topham C, Bonetti A, Clingan P, Bridgewater J, Rivera F, et al: Improved overall survival with oxaliplatin, fluorouracil, and leucovorin as adjuvant treatment in stage II or III colon cancer in the MOSAIC trial. J Clin Oncol 2009. 27(19):3109-3116.

5. Pohl A, Lurje G, Manegold PC, Lenz HJ: Pharmacogenomics and -genetics in colorectal cancer. Adv Drug Deliv Rev 2009, 61(5):375-380.

6. Ribic CM, Sargent DJ, Moore MJ, Thibodeau SN, French AJ, Goldberg RM, Hamilton SR, Laurent-Puig P, Gryfe R, Shepherd LE, et al: Tumor microsatellite-instability status as a predictor of benefit from fluorouracil-based adjuvant chemotherapy for colon cancer. N Engl J Med 2003, 349(3):247-257.

7. Ogunbiyi OA, Goodfellow PJ, Herfarth K, Gagliardi G, Swanson PE, Birnbaum EH, Read TE, Fleshman JW, Kodner IJ, Moley JF: Confirmation that chromosome $18 \mathrm{q}$ allelic loss in colon cancer is a prognostic indicator. J Clin Oncol 1998, 16(2):427-433.

8. Russo A, Bazan V, lacopetta B, Kerr D, Soussi T, Gebbia N: The TP53 colorectal cancer international collaborative study on the prognostic and predictive significance of p53 mutation: influence of tumor site, type of mutation, and adjuvant treatment. J Clin Oncol 2005, 23(30):7518-7528.

9. Allegra CJ, Paik S, Colangelo LH, Parr AL, Kirsch I, Kim G, Klein P, Johnston PG, Wolmark N, Wieand HS: Prognostic value of thymidylate synthase, Ki-67, and p53 in patients with Dukes' B and C colon cancer: a National Cancer Institute-National Surgical Adjuvant Breast and Bowel Project collaborative study. J Clin Oncol 2003, 21(2):241-250.
10. Popat S, Chen Z, Zhao D, Pan H, Hearle N, Chandler I, Shao Y, Aherne W, Houlston R: A prospective, blinded analysis of thymidylate synthase and p53 expression as prognostic markers in the adjuvant treatment of colorectal cancer. Ann Oncol 2006, 17(12):1810-1817.

11. Kim GP, Colangelo LH, Wieand HS, Paik S, Kirsch IR, Wolmark N, Allegra CJ: Prognostic and predictive roles of high-degree microsatellite instability in colon cancer: a National Cancer Institute-National Surgical Adjuvant Breast and Bowel Project Collaborative Study. J Clin Oncol 2007 25(7):767-772

12. Popat S, Zhao D, Chen Z, Pan H, Shao Y, Chandler I, Houlston RS: Relationship between chromosome $18 \mathrm{q}$ status and colorectal cancer prognosis: a prospective, blinded analysis of 280 patients. Anticancer Res 2007, 27(1B):627-633.

13. Mantovani A, Cassatella MA, Costantini C, Jaillon S: Neutrophils in the activation and regulation of innate and adaptive immunity. Nat Rev Immuno 201l, 11(8):519-531.

14. de Visser KE, Eichten A, Coussens LM: Paradoxical roles of the immune system during cancer development. Nat Rev Cancer 2006, 6(1):24-37.

15. Coletta PL, Muller AM, Jones EA, Muhl B, Holwell S, Clarke D, Meade JL, Cook GP, Hawcroft G, Ponchel F, et al: Lymphodepletion in the ApcMin/+ mouse model of intestinal tumorigenesis. Blood 2004, 103(3):1050-1058.

16. Zocchi MR, Poggi A: Targeting the Microenvironment in Hematological Malignancies: How to Condition both Stromal and Effector Cells to Overcome Cancer Spreading. Curr Med Chem 2011, 18(34):5172-5173.

17. Bolotin E, Annett G, Parkman R, Weinberg K: Serum levels of IL-7 in bone marrow transplant recipients: relationship to clinical characteristics and lymphocyte count. Bone Marrow Transplant 1999, 23(8):783-788.

18. Malaspina A, Moir S, Chaitt DG, Rehm CA, Kottilil S, Falloon J, Fauci AS: Idiopathic CD4+ T lymphocytopenia is associated with increases in immature/transitional B cells and serum levels of IL-7. Blood 2007, 109(5):2086-2088.

19. Ming J, Jiang G, Zhang Q, Qiu X, Wang E: Interleukin-7 up-regulates cyclin D1 via activator protein-1 to promote proliferation of cell in lung cancer. Cancer Immunol Immunother 2012, 61(1):79-88.

20. Cattaruzza L, Gloghini A, Olivo K, Di Francia R, Lorenzon D, De Filippi R, Carbone A, Colombatti A, Pinto A, Aldinucci D: Functional coexpression of Interleukin (IL)-7 and its receptor (IL-7R) on Hodgkin and Reed-Sternberg cells: Involvement of IL-7 in tumor cell growth and microenvironmental interactions of Hodgkin's lymphoma. Int J Cancer 2009, 125(5):1092-1101.

21. Ming J, Zhang Q, Qiu X, Wang E: Interleukin 7/interleukin 7 receptor induce c-Fos/c-Jun-dependent vascular endothelial growth factor-D upregulation: a mechanism of lymphangiogenesis in lung cancer. Eur J Cancer 2009, 45(5):866-873.

22. Roato I, Caldo D, Godio L, D'Amico L, Giannoni P, Morello E, Quarto R, Molfetta $L$, Buracco P, Mussa A, et al: Bone invading NSCLC cells produce IL-7: mice model and human histologic data. BMC Cancer 2010, 10:12.

23. Roato I, Brunetti G, Gorassini E, Grano M, Colucci S, Bonello L, Buffoni L, Manfredi R, Ruffini E, Ottaviani D, et al: IL-7 up-regulates TNF-alpha -dependent osteoclastogenesis in patients affected by solid tumor. PLoS One 2006, 1:e124.

24. Kitayama J, Yasuda K, Kawai K, Sunami E, Nagawa H: Circulating lymphocyte is an important determinant of the effectiveness of preoperative radiotherapy in advanced rectal cancer. BMC Cancer 2011, 11:64.

25. Ceze N, Thibault G, Goujon G, Viguier J, Watier H, Dorval E, Lecomte T: Pretreatment lymphopenia as a prognostic biomarker in colorectal cancer patients receiving chemotherapy. Cancer Chemother Pharmaco 2011, 68(5):1305-1313.

26. Kim YR, Kim JS, Kim SJ, Jung HA, Kim SJ, Kim WS, Lee HW, Eom HS, Jeong $\mathrm{SH}$, Park JS, et al: Lymphopenia is an important prognostic factor in peripheral T-cell lymphoma (NOS) treated with anthracycline-containing chemotherapy. J Hematol Oncol 2011, 4:34.

27. Ray-Coquard I, Cropet C, Van Glabbeke M, Sebban C, Le Cesne A, Judson I, Tredan O, Verweij J, Biron P, Labidi I, et al: Lymphopenia as a prognostic factor for overall survival in advanced carcinomas, sarcomas, and lymphomas. Cancer Res 2009, 69(13):5383-5391.

28. Sakamoto J, Kondo Y, Takemiya S, Sakamoto N, Nishisho I: A phase II Japanese study of a modified capecitabine regimen for advanced or metastatic colorectal cancer. Anticancer Drugs 2004, 15(2):137-143.

29. Wagstaff AJ, Ibbotson T, Goa KL: Capecitabine: a review of its pharmacology and therapeutic efficacy in the management of advanced breast cancer. Drugs 2003, 63(2):217-236. 
30. Dufresne A, Bertucci F, Penel N, Le Cesne A, Bui B, Tubiana-Hulin M, RayCoquard I, Cupissol D, Chevreau C, Perol D, et al: Identification of biological factors predictive of response to imatinib mesylate in aggressive fibromatosis. Br J Cancer 2010, 103(4):482-485.

31. Lissoni P, Brivio F, Fumagalli L, Di Fede G, Brera G: Enhancement of the efficacy of chemotherapy with oxaliplatin plus 5 -fluorouracil by pretreatment with IL-2 subcutaneous immunotherapy in metastatic colorectal cancer patients with lymphocytopenia prior to therapy. In Vivo 2005, 19(6):1077-1080.

32. Cretel E, Veen I, Pierres A, Binan Y, Robert P, Loundou AD, BaumstarckBarrau K, Hubert AM, Bongrand P, Heim M: Immune profile of elderly patients admitted in a geriatric short care unit. Rev Med Interne 2011, 32(5):275-282.

33. Arrieta O, Michel Ortega RM, Villanueva-Rodriguez G, Serna-Thome MG, Flores-Estrada D, Diaz-Romero C, Rodriguez CM, Martinez L, Sanchez-Lara K: Association of nutritional status and serum albumin levels with development of toxicity in patients with advanced non-small cell lung cancer treated with paclitaxel-cisplatin chemotherapy: a prospective study. BMC Cancer 2010, 10:50

34. Hart AJ, Skinner JA, Winship P, Faria N, Kulinskaya E, Webster D, MuirheadAllwood S, Aldam CH, Anwar H, Powell Jj: Circulating levels of cobalt and chromium from metal-on-metal hip replacement are associated with CD8+ T-cell lymphopenia. J Bone Joint Surg Br 2009, 91(6):835-842.

35. Fock RA, Blatt SL, Beutler B, Pereira J, Tsujita M, de Barros FE, Borelli P: Study of lymphocyte subpopulations in bone marrow in a model of proteinenergy malnutrition. Nutrition 2010, 26(10):1021-1028.

36. Andre T, Boni C, Mounedji-Boudiaf L, Navarro M, Tabernero J, Hickish T, Topham C, Zaninelli M, Clingan P, Bridgewater J, et al: Oxaliplatin, fluorouracil, and leucovorin as adjuvant treatment for colon cancer. N Engl J Med 2004, 350(23):2343-2351.

doi:10.1186/1471-2407-13-177

Cite this article as: Chu-Yuan et al:: The impact of chemotherapyassociated neutrophil/ lymphocyte counts on prognosis of adjuvant chemotherapy in colorectal cancer. BMC Cancer 2013 13:177.

\section{Submit your next manuscript to BioMed Central and take full advantage of:}

- Convenient online submission

- Thorough peer review

- No space constraints or color figure charges

- Immediate publication on acceptance

- Inclusion in PubMed, CAS, Scopus and Google Scholar

- Research which is freely available for redistribution 